\title{
An investigation of equine infectious anaemia infection in the Central Anatolia region of Turkey
}

\author{
O Yapkıç ${ }^{a}$, S Yavru ${ }^{a}$, M Kale ${ }^{b^{*}}$, O Bulut ${ }^{a}$, A Şimşek ${ }^{a}$ and K C Şahna ${ }^{c}$
}

\begin{abstract}
In this study, 162 horses, 80 donkeys and 51 mule serum samples were collected in Konya city. Additionally, 64 horse serum samples from Ankara and 49 samples from Kayseri city were included in the study. A total of 406 serum samples were examined by agar gel immunodiffusion (AGID) and enzyme-linked immunosorbent assay (ELISA) for antibody to equine infectious anaemia virus (EIAV) and no positive result was detected.
\end{abstract}

Key words: donkey, equine infectious anaemia, horse, mule, Turkey.

Yapkıç O, Yavru S, Kale M, Bulut O, Şimşek A, Şahna K C An investigation of equine infectious anaemia infection in the central Anatolia region of Turkey. Journal of the South African Veterinary Association (2007) 78(1): 12-14 (En.). Department of Virology, Faculty of Veterinary Medicine, Akdeniz University, 15100, Burdur-Turkey.

\section{INTRODUCTION}

Equine infectious anaemia (EIA) is a chronic disease of all members of equidae, including horses, donkeys, mules, ponies and zebra. It is characterised by periodical fever, anaemia, thrombocytopaenia and leukopaenia $^{4,10}$. Equine infectious anaemia virus infection is of considerable importance for the equine industry ${ }^{16}$. The prevalence of infection varies throughout the world and depends on the density of the horse population, the proportion of carrier animals, the insect vector population, and control activities in the particular $\operatorname{area}^{27}$. EIA has a worldwide distribution and has been diagnosed on all continents except Antarctica. The virus is endemic to the Americas, parts of Europe, the Middle and Far East, Russia and South Africa ${ }^{1,7,11}$. Transmission occurs mechanically by transfer of blood from an infected horse. In nature, spread of the virus is most likely via interrupted feeding of bloodsucking horseflies on a clinically ill horse and then on susceptible horses, or from the use of contaminated needles ${ }^{22}$. Most naturally occurring outbreaks of acute and subacute cases of this disease develop during the late summer and early autumn months in the temperate zone. This coincides with the peak of the biting insect population, especially bloodsucking horseflies, deer

aDepartment of Virology, Faculty of Veterinary Medicine University of Selcuk, Campus-Konya, Turkey.

bDepartment of Virology, Faculty of Veterinary Medicine University of Akdeniz, Burdur, Turkey.

${ }^{\mathrm{C}}$ Department of Virology, Faculty of Veterinary Medicine, University of Erciyes, Kayseri, Turkey.

*Author for correspondence.

E-mail: drmkalex@yahoo.com

Received: June 2006. Accepted: December 2006. flies (tabanids), stable flies (Stomoxys spp.), mosquitoes and possibly midges ${ }^{12,17,24,26}$. Biting insects, such as deer flies, horse flies and stable flies rather than mosquitoes, are generally considered to play a primary role in mechanical transmission of the EIA virus ${ }^{20}$. The fly population of the Mediterranean and southeastern Anatolian regions of Turkey and animal movement increases in summer; therefore, the disease could spread quickly and easily in Turkey.

Once a horse is infected with EIA virus, its blood remains infectious for the remainder of its life. This means that the horse is a viraemic carrier and can potentially transmit the infection to other susceptible animals $^{8,34}$. The most important factor for prevention of EIAV infection is separation of infected from healthy animals. Thus, the animals should be tested periodically with serological tests and seropositive animals should be considered as persistently infected even if no obvious clinical signs are seen, and these animals should be isolated from healthy animals ${ }^{18}$. The most useful serological tests for screening of EIAV infection are AGID and ELISA ${ }^{8,13}$. The AGID test, widely known as Coggin's test, has been approved by United States Department of Agriculture (USDA) for diagnosis of EIAV infection, but many researchers state that ELISA is more sensitive than $\mathrm{AGID}^{2,25}$.

The health statement for European Union (EU) intra-Community movement requires all horses to be clinically examined and declared healthy prior to movement. The requirement for health certificates and clinical examinations prior to move- ment does, however, not apply to the movement of registered horses under the Tripartite Agreement (TPA) between the United Kingdom, Republic of Ireland and France $^{11}$. The EIA status of most of the horse, donkey and mule populations in Turkey is largely unknown as surveillance is not carried out. Usually only a relatively few horses (mainly racing horses and horses on large farms) are closely monitored and possibly tested for EIA. In this study, serum samples were collected from privately owned horses, donkeys and mules. The purpose of the present study was to investigate the prevalence of EIA antibodies in horses, donkeys, and mules in the Central Anatolia region of Turkey.

\section{MATERIALS AND METHODS}

The Central Anatolia region is predominantly an agricultural region and has many working horses belonging to villagers, who breed horses in small studs for carrying their belongings. The total number of horses, donkeys and mules in the region is about $41000^{29}$.

In this study, the Simple Random Sampling technique of the Regional Sampling method was used ${ }^{35}$. Random sampling points were selected in three provinces in the Central Anatolia region. Sample units close to these points were then determined, and the selected animals were considered representative of the population. Blood samples were collected from 275 horses, 80 donkeys and 51 mules older than 3 years without clinical signs of the disease (Table 1). Blood samples were placed in clot activator vacuum tubes and centrifugated at $3000 \mathrm{rpm}$ for 10 minutes. The separated serum samples were heatinactivated at $56^{\circ} \mathrm{C}$ for 30 minutes before testing. Commercial AGID kits were obtained from VMRD Inc. (Pulman, WA, USA), and the test was carried according to the manufacturer's instructions. The agar was prepared as a $1 \%$ solution of noble agar in $14.5 \mathrm{~m} \ell$ borate buffer ( $\mathrm{pH} 8.6) ; 15 \mathrm{ml}$ of it was then transferred to plastic Petri dishes. The test pattern consisted of six peripheral wells around a centre well: $50 \mu l$ of antigen was placed in the centre well, reference positive serum 
$(50 \mu l)$ was added to one peripheral well, and the other five wells were used for test serums $(50 \mu l)$. The Petri dishes were then incubated for 24-48 hours at room temperature to form the precipitin line that is characteristic of a positive sample, whereafter the results were recorded. Suspect samples were retested by AGID. A commercial ELISA (Viral Antigen Inc., Memphis, TN, USA) test kit was also used as a different technique. The results were evaluated spectrophotometrically at $450 \mathrm{~nm}$ adsorbance.

\section{RESULTS}

Two hundred and fifty owners from the main cities (Konya, Ankara, Kayseri) of the Central Anatolia region agreed to cooperate in the study. A total of 406 animals (275 horses, 80 donkeys and 51 mules) was tested. All horses, donkeys and mules were negative for antibodies to EIAV.

\section{DISCUSSION}

EIA infection is prevalent in all parts of the world and it is of importance for the equine industry ${ }^{26,28}$. EIA is a notifiable disease in Turkey and there are official rules and regulations about EIA infection in Turkey ${ }^{23}$.

Besides the several serological tests for the diagnosis of the infection, AGID and ELISA have been reported as the most sensitive tests and they have been used by many researchers ${ }^{4,13}$. AGID tests and ELISAs are accurate, reliable tests for the detection of EIA in horses, except for animals in the early stages of infection and foals of infected dams ${ }^{28,32}$. Confirmation of a clinical diagnosis of EIA was hampered until 1970 by the lack of a simple, reliable diagnostic test. The successful adaptation of the AGID test for the diagnosis of EIA by Coggins and Norcross ${ }^{6}$ provided a reliable and economical diagnostic tool. Additionally, the ELISA has been successfully used for determination of antibodies against EIAV by many researchers, and a good correlation between two tests was found 22,33 .

Donkeys and mules have been traditionally used for transport as have horses in Turkey and these animals are kept by local people and are generally unregistered. In previous studies ${ }^{3,5,36}$ evaluating EIA prevalence in horses in Turkey using the AGID test, and in horses, donkeys and mules using both the AGID and ELISA, no seropositivity for EIA was documented. In the current study, the prevalence of antibodies against EIA was studied in horses, donkeys and mules only from the Central Anatolia region using both AGID and ELISA. In total, 406 serum samples were collected in three cities (Table 1),

Table 1: Distribution of serum samples of horses, donkeys and mules from 3 cities in the Central Anatolia region of Turkey.

\begin{tabular}{lrccr}
\hline Animals & \multicolumn{3}{c}{ Central Anatolia } & Total \\
\cline { 2 - 5 } & Konya & Ankara & Kayseri & \\
\hline Horse & 162 & 64 & 49 & 275 \\
Donkey & 80 & - & - & 80 \\
Mule & 51 & - & - & 51 \\
Total & 293 & 64 & 49 & 406 \\
\hline
\end{tabular}

and none of them was positive. This situation shows that the disease is not present or that it might be present but could not be detected because of the low sampling numbers or because the immune response of those animals had not yet been mounted. The virus titre, however, is higher in horses with clinical signs and the risk of transmission is higher from these animals than the carrier animals with lower titres ${ }^{19}$. High plasma viraemia levels characterise the first disease episode, which is usually referred to as the acute stage of equine infectious anaemia ${ }^{9}$. Donkeys and mules infected with two strains of EIAV had significantly lower amounts of plasma-associated virus and/or viral nucleic acid levels than similarly infected horse or pony controls during the critical early stages following infection ${ }^{10,31}$. As was concluded in this study, researchers in previous studies $^{3,5,15,22,30,33,36,37}$ reported that no seropositivity was detected in horses, donkeys and mules with no clinical signs and they attributed this to the health of all animals or that the animals were in the early stages of acute EIA. Asymptomatic and suspected animals may be detected by using a more sensitive technique, such as polymerase chain reaction (PCR), to test for viral nucleic acids in blood or tissues $^{14,21}$.

\section{CONCLUSION}

In this research, besides the horse sera, donkey and mule samples were tested because these animals also play a role as carriers. Regions with high density horse, donkey and mule populations and sampling units close to these regions were selected, with a homogenous distribution of animals in the selected regions. It is concluded that EIA is not present the Central Anatolia region of Turkey and that EIA offers no potential risks for the horse-breeding and racing industry in this part Turkey.

\section{REFERENCES}

1. APHIS 2006. Equine infectious anemia: uniform methods and rules, effective. The United States Department of Agriculture Publications, USA

2. Archaumbault D, Wang Z, Lacal J C, Gazit A, Yaniv A, Dahlberg J E, Tronick S R 1989
Development of an enzyme linked immunosorbent assay for equine infectious anemia virus detection using recombinant Pr55 ${ }^{\text {gag }}$. Journal of Clinical Microbiology 27: 1167-1173

3. Ataseven V S, Arslan H H 2005 Equine infectious anemia in mules, donkeys, and horses: epidemiologic studies in the different geographic regions of Turkey. Journal of Equine Veterinary Science 25: 439441

4. Ball J M, Henry N L, Montelaro R C, Newman M J 1994 A versatile synthetic peptide based ELISA for identifying antibody epitopes. Journal of Immunological Methods 171: 37-44

5. Burgu I, Akça Y, Toker A, Alkan F 1989 Atlarda enfeksiyöz anemi'nin serolojik olarak araștırılması. Ankara Üniversitesi Veteriner Fakültesi Dergisi 36: 123-128

6. Coggins L, Norcross N L 1970 Immunodiffusion reaction in equine infectious anemia. Cornell Veterinarian 60: 330-335

7. Coggins L, Auchnie J A 1977 Control of equine infectious anemia in horses in Hong Kong. Journal of the American Veterinary Medical Association 170: 1299-1301

8. Coggins L 1984 Carriers of equine infectious anemia virus. Journal of the American Veterinary Medical Association 184: 279-281

9. Cook R F, Issel C J, Montelaro R C 1996 Equine infectious anemia. In Studdert $\mathrm{M} \mathrm{J}$ (eds) Virus infections of equines Vol. 1. Elsevier Publishing, Amsterdam: 297-323

10. Cook S J, Cook R F, Montelaro R C, Issel C J 2001 Differential responses of Equine caballus and Equine asinus to infection with two pathogenic strains of equine infectious anemia virus. Veterinary Microbiology 79: 93-109

11. DEFRA 2006 Equine infectious anaemia: Potential risk factors for the introduction of the virus to Great Britain from EU member states and countries neighbouring the EU. International Disease Monitoring Unit Qualitative Risk Assessments 1: 1-16

12. Foil L D, Meek C L, Adams W V, Issel C J 1983 Mechanical transmission of equine infectious anemia virus by deer flies (Chrysops flavidus) and stable flies (Stomoxys calcitrans). American Journal of Veterinary Research 44: $155-156$

13. Grund C H, Lechman E R, Pezzuolo N A, Issel C J, Montelaro R C 1996 Fine specificity of equine infectious anaemia virus gp90specific antibodies associated with protective and enhancing immune responses in experimentally infected and immunized ponies. Journal of General Virology 77: 435-442

14. Harrold S M, Cook S J, Cook R F, Rushlow K E, Issel C J, Montelaro R C 2000 Tissue sites of persistent infection and active replication of equine infectious anemia virus during acute disease and asymptomatic infection in experimentally infected equids. 
Journal of Virology 74: 3112-3121

15. Hedger R S, Barnett I T, Gray D F 1980 Some virus diseases of domestic animals in the sultanate of Oman. Tropical Animal Health Production 12: 107-114

16. Hussain K A, Issel C J, Rwambo P M, Arnizaut A B, Ball J M, Schnorr K L, Montelaro R C 1988 Identification of gag precursor of equine infectious anemia virus with monoclonal antibodies to the major viral core protein, p26. Journal of General Virology 69: 1719-1724

17. Issel C J, Foil L D 1984 Studies on equine infectious anemia virus transmission by insects. Journal of the American Veterinary Medical Association 184: 293

18. Issel C J, McManus J M, Hagius S D, Foil L D, Adams W V, Montelaro R C 1990 Equine infectious anemia: prospects for control. Developments in Biological Standardization 72 : 49-57

19. Kemen M J, Coggins L 1972 Equine infectious anaemia: transmission from infected mares to foals. Journal of the American Veterinary Medical Association 161: 496-499

20. Kemen M J, McClain D S, Matthysse J G 1978 Role of horse flies in transmission of equine infectious anemia from carrier ponies. Journal of American Veterinary Medical Association 172: 360-362

21. Langemeier J L, Cook S J, Cook R F, Rushlow K E, Montelaro R C, Issel C J 1996 Detection of equine infectious anemia viral RNAin plasma samples from recently infected and long-term inapparent carrier animals by PCR. Journal of Clinical
Microbiology 34: 1481-1487

22. Lew A M, Thomas L M, Huntington PJ 1993 A comparison of ELISA, FAST-ELISA and gel diffusion tests for detecting antibody to equine infectious anaemia virus. Veterinary Microbiology 34: 1-5

23. Mara 2004 The law of animal health control. General Directorate of Protection and Control Republic of Turkey, Ministry of Agriculture and Rural Affairs Publications, Ankara

24. Mattioli R C, Zinsstag J, Pfister K 1992 African horse sickness and equine infectious anemia serology in the Gambia. Tropical Animal Health and Production 24: 207-208

25. McGuire T C 1977 Immunoglobulin G subclass (IgG and IgG-T) interaction with the p26 group specific antigen of equine infectious anemia virus: immunodiffusion and complement-fixation reactions. American Journal of Veterinary Research 38: 655-658

26. Motie A 1986 An outbreak of suspected equine infectious anemia in Guyana. British Veterinary Journal 142: 36-40

27. OIE 2005 Equine infectious anemia. Manual of Diagnostic Tests and Vaccines for Terrestrial Animals 2: 1-9

28. Pearson J E, Knowles R C 1984 Standardization of the equine infectious anemia immunodiffusion test and its application to the control of the disease in the United States. Journal of the American Veterinary Medical Association 184: 298-301

29. SIS 2004 Agricultural structure (production, price and value). The State Institute of Statistics Prime Ministry Republic of Turkey Publications, Ankara
30. Smith V W, Coackley W, Maker D 1980 Absence of equine infectious anaemia in the Kimberley region of Western Australia. Australian Veterinary Journal 56: 255

31. Spyrou V, Papanastassopoulou M, Psychas V, Billinis Ch, Koumbati M, Vlemmas J, Koptopoulos G 2003 Equine infectious anemia in mules: virus isolation and pathogenicity studies.Veterinary Microbiology 95: 49-59

32. Suzuki T, Ueda S, Samejina T 1982 Enzymelinked immunosorbent assay for diagnosis of equine infectious anaemia. Veterinary Microbiology 7: 307-316

33. Tashjian R J 1984 Transmission and clinical evaluation of an equine infectious anemia herd and their offspring over a 13-year period. Journal of the American Veterinary Medical Association 184: 282-288

34. Tencza S B, Islam K R, Kalia V, Nasir M S, Jolley M E, Montelaro R C 2000 Development of a fluorescence polarization-based diagnostic assay for equine infectious anemia virus. Journal of Clinical Microbiology 38: 1854-1859

35. Thrusfield M 1997 Veterinary Epidemiology (2nd edn). Blackwell Publishing, Oxford, UK

36. Turan N, Yilmaz H, Uysal A, Arslan M 2002 Seronegative findings on the investigations of equine infectious anemia in the Marmara region of Turkey. Turkish Journal of Veterinary and Animal Science 26: 299-302

37. Uppal P K, Yadav M P 1989 Occurrence of equine infectious anemia in India. Veterinary Record 13: 514-515 